\title{
Tissue-Engineered Solutions in Plastic and Reconstructive Surgery: Principles and Practice
}

\author{
Sarah Al-Himdani 1,2†, Zita M. Jessop 1,2†, Ayesha Al-Sabah' ${ }^{1}$,Emman Combellack ${ }^{1,2}$, \\ Amel Ibrahim ${ }^{1,2,3}$, Shareen H. Doak ${ }^{1,4}$, Andrew M. Hart ${ }^{5}$, Charles W. Archer ${ }^{1,6}$, \\ Catherine A. Thornton ${ }^{1,7}$ and lain S. Whitaker ${ }^{1,2 *}$
}

${ }^{1}$ Reconstructive Surgery and Regenerative Medicine Research Group (ReconRegen), Institute of Life Science, Swansea University Medical School, Swansea, UK, ${ }^{2}$ The Welsh Centre for Burns and Plastic Surgery, Morriston Hospital, Swansea, UK, ${ }^{3}$ Institute of Child Health, University College London, London, UK, ${ }^{4}$ In Vitro Toxicology Group, Institute of Life Science, Swansea University Medical School, Swansea, UK, ${ }^{5}$ Canniesburn Plastic Surgery Unit, Centre for Cell Engineering, University of Glasgow, Glasgow, UK, ${ }^{6}$ Cartilage Biology Research Group, Institute of Life Science, Swansea University Medical School, Swansea, UK, ${ }^{7}$ Human Immunology Group, Institute of Life Science, Swansea University Medical School, Swansea, UK

Recent advances in microsurgery, imaging, and transplantation have led to significant

OPEN ACCESS

Edited by:

Jan A. Plock,

University of Zurich, Switzerland

Reviewed by:

Fatih Zor,

Gulhane Military Medical Academy, Turkey

Michael P. Chae,

Peninsula Health, Australia

*Correspondence:

lain S. Whitaker

i.s.whitaker@swansea.ac.uk

${ }^{\dagger}$ Joint first authors.

Specialty section:

This article was submitted to Reconstructive and Plastic Surgery,

a section of the journal

Frontiers in Surgery

Received: 08 December 2016 Accepted: 18 January 2017

Published: 23 February 2017

Citation:

Al-Himdani S, Jessop ZM,

Al-Sabah A, Combellack E,

Ibrahim A, Doak SH, Hart AM,

Archer CW, Thornton CA and

Whitaker IS (2017) Tissue-Engineered

Solutions in Plastic and

Reconstructive Surgery: Principles and Practice.

Front. Surg. 4:4.

doi: 10.3389/fsurg.2017.00004 refinements in autologous reconstructive options; however, the morbidity of donor sites remains. This would be eliminated by successful clinical translation of tissue-engineered solutions into surgical practice. Plastic surgeons are uniquely placed to be intrinsically involved in the research and development of laboratory engineered tissues and their subsequent use. In this article, we present an overview of the field of tissue engineering, with the practicing plastic surgeon in mind. The Medical Research Council states that regenerative medicine and tissue engineering "holds the promise of revolutionizing patient care in the twenty-first century." The UK government highlighted regenerative medicine as one of the key eight great technologies in their industrial strategy worthy of significant investment. The long-term aim of successful biomanufacture to repair composite defects depends on interdisciplinary collaboration between cell biologists, material scientists, engineers, and associated medical specialties; however currently, there is a current lack of coordination in the field as a whole. Barriers to translation are deep rooted at the basic science level, manifested by a lack of consensus on the ideal cell source, scaffold, molecular cues, and environment and manufacturing strategy. There is also insufficient understanding of the long-term safety and durability of tissue-engineered constructs. This review aims to highlight that individualized approaches to the field are not adequate, and research collaboratives will be essential to bring together differing areas of expertise to expedite future clinical translation. The use of tissue engineering in reconstructive surgery would result in a paradigm shift but it is important to maintain realistic expectations. It is generally accepted that it takes 20-30 years from the start of basic science research to clinical utility, demonstrated by contemporary treatments such as bone marrow transplantation. Although great advances have been made in the tissue engineering field, we highlight the barriers that need to be overcome before we see the routine use of tissue-engineered solutions.

Keywords: tissue engineering, regenerative medicine, stem cells, translation, bioengineering, barriers to translation, translational research, plastic and reconstructive surgery 


\section{INTRODUCTION}

Reconstructive plastic surgery aims to provide living tissue in order to restore both form and function following a wide range of congenital or acquired defects. Operations are complex, often transcending anatomic boundaries. Versatility resulting from surgery on a full range of tissues including skin, fat, nerve, muscle, bone, and cartilage promotes innovation, and with the recent advances in medical imaging (1), microsurgery (2), vascularized composite allotransplantation $(3,4)$, nanotechnology $(5)$, cell biology, biomaterials (6), and 3D printing (7-10), treatment options for patients are wider than ever before. Even armed with new reconstructive options based on microsurgical principles and transplantation, surgeons have become increasingly cognizant that there is the real potential for a paradigm shift in reconstructive surgery in the medium term via tissue-engineered solutions. The implementation into practice could potentially eliminate the need for donor sites and their morbidity, reduce hospital stay and associated costs (11).

\section{Relevance of This Article}

Contrary to public perception, the diverse workload of reconstructive plastic surgeons comprises a relatively small proportion of purely esthetic procedures (12). The majority of operations undertaken pertain to neoplasia and wound management, with a significant health economic impact (12). Over one million patients are treated per year in NHS England by Plastic Surgeons $(13,14)$, with evidence suggesting that this workload will continue to increase (15). If you extrapolate these figures worldwide, it is easy to see the clinical need is vast. As a group, reconstructive surgeons are facing more challenging composite defects than ever before coupled with Internet and media savvy patients with increasing expectations (16). Technological innovation in reconstructive surgery in the twentieth century offered the possibility for surgeons to operate on microvascular structures enabling free tissue transfers (2) and extremity replantations. Despite these developments in practice, we are still confronted with shortcomings relating to the availability of donor tissues. In order to overcome this, novel approaches have been investigated. Among these approaches, the most attractive concept is tissue engineering.

Tissue engineering is a modern, interdisciplinary field combining principles of engineering, physics, and the life sciences. It shares a common objective with plastic and reconstructive surgery; "to restore form and function" $(17,18)$. The long-term aim of tissue engineering is to biomanufacture autologous, vascularized, physiologically relevant solutions to repair and restore complex defects. Successful biomanufacture will depend on the correct blend of cell source, suitable scaffold and ideal microenvironment (19). Answers to these fundamental questions rely on interdisciplinary collaboration between cell biologists, material scientists, biotechnologists, and associated medical specialties (20). Upscaling and widespread use in health services will need close interaction with the cell therapy industry and associated manufacturers.

The surgical community worldwide is becoming increasingly aware of the research landscape. The American Society of Plastic surgeons have highlighted the role of tissue engineering in the future of plastic surgery (21), particularly the need for a focus on translation from bench research to clinical practice. In the United Kingdom, the House of Lords recognized the potential of regenerative medicine to impact on the health service and highlighted the current "lack of coordination" in the field as a whole $(22,23)$. Recommendations included the development of multidisciplinary working groups (basic scientists, clinicians, investors, manufacturing experts, and regulators), as well as governmental support to drive forward the agenda on regenerative medicine.

There is a need to develop NHS capacity with regional facilities licensed for Good Laboratory Practice (GLP) and current Good Manufacturing Practices (cGMP), which are engaged with a clinical specialty skilled in the manipulation of cells and the viable insertion of tissue-engineered constructs. Skilled in vascularization and in tissue viability/transfer, plastic surgeons already fulfill this role as an interface specialty delivering complex reconstructive techniques to a broad range of other specialties. The regional service structure of plastic surgery within the NHS would further support their capacity to align with regional cGMP facilities and deliver tissue-engineering solutions to a range of medical and surgical specialties.

\section{Objectives}

\section{Assess the Shortcomings Of}

Traditional Reconstructive Options

Up till now, restoration of form and function has relied on the use of autologous (rarely allogeneic) tissue, alloplastic implants, or a combination of the two. Although effective, these options have disadvantages that merit highlighting (Table 1).

\section{Tissue-Engineered Solutions}

Although tissue-engineered solutions hold great promise, we must be realistic in that contemporary tissue-engineered constructs implanted into immune-competent animal models have been observed to undergo inflammation, fibrosis, foreign body reaction, and degradation (Table 1; Figure 1). One of the major problems remains vascularization of larger volume constructs (24), and an issue coming to the fore in modern literature is the potential for tumorigenesis (25).

\section{Provide an Overview Of}

\section{Fundamental Principles of Tissue Engineering: Cell Source,} Scaffold, Assembly Method, and Molecular and Mechanical Signaling

We discuss the multiple considerations for tissue engineering research in order to highlight the complexity of the field as a whole. This supports the argument for multidisciplinary coordination, which is required to take the field forward. The fundamental principles are summarized in Figure 2: cell source, scaffolds, assembly method, subsequent growth (molecular and mechanical signaling), and patient safety. These factors all contribute to the "environment" (19). In simple terms, the cell is required for synthesis of the new tissue matrix, while the scaffold, biomolecules, and the microenvironment provide trophic cues to guide proliferation and differentiation. Growth, induction, and 
TABLE 1 | Advantages and shortcomings of reconstructive solutions for managing tissue defects.

\begin{tabular}{|c|c|c|}
\hline Reconstructive solution & Advantages & Disadvantages \\
\hline Autologous & $\begin{array}{l}\text { - No immunological complications } \\
\text { - No ethical constraints } \\
\text { - Biologically compatible } \\
\text { - Minimal degradation } \\
\text { - Fewer legal restrictions } \\
\text { - No disease transmission } \\
\text { - Challenging harvesting cells in aged or diseased }\end{array}$ & $\begin{array}{l}\text { - Donor site morbidity } \\
\text { - Limited quantity of tissue available } \\
\text { - Two separate operative sites - greater risk and cost }\end{array}$ \\
\hline Allogeneic & $\begin{array}{l}\text { - No donor site morbidity } \\
\text { - Donor cells may have higher viability } \\
\text { - Tissue always healthy } \\
\text { - Greater quantity of available tissue }\end{array}$ & $\begin{array}{l}\text { - Temporary (i.e., cadaveric skin used in extensive burns) } \\
\text { - Tissue typing is required } \\
\text { - Immunosuppression may be needed } \\
\text { - Risk of disease transmission } \\
\text { - Greater legal hurdles } \\
\text { - Ethical and psychological challenges }\end{array}$ \\
\hline Synthetic & $\begin{array}{l}\text { - Maintain structural integrity } \\
\text { - Predictable and reproducible physical and mechanical } \\
\text { properties } \\
\text { - Cost effective } \\
\text { - Avoids concerns over disease transmission }\end{array}$ & $\begin{array}{l}\text { - Extrusion } \\
\text { - Infection } \\
\text { - Cannot restore all of specialized tissue/organ functions } \\
\text { - Do not respond to biological cues/grow with patient } \\
\text { - May provoke an immune/inflammatory/fibrotic reaction } \\
\text { - Materials safety testing and manufacturing governance }\end{array}$ \\
\hline Tissue engineered & $\begin{array}{l}\text { - Biocompatible } \\
\text { - Good biofunctionality } \\
\text { - Good retention of size and shape } \\
\text { - No donor site morbidity } \\
\text { - Unlimited expansion of cells/tissues } \\
\text { - No immunological concerns } \\
\text { - Mechanical stability }\end{array}$ & $\begin{array}{l}\text { - Long-term effect unknown } \\
\text { - Size often limited by vascularity } \\
\text { - Costly } \\
\text { - Tumorigenic potential } \\
\text { - Difficult to engineer "physiologically relevant/mature tissue" }\end{array}$ \\
\hline
\end{tabular}

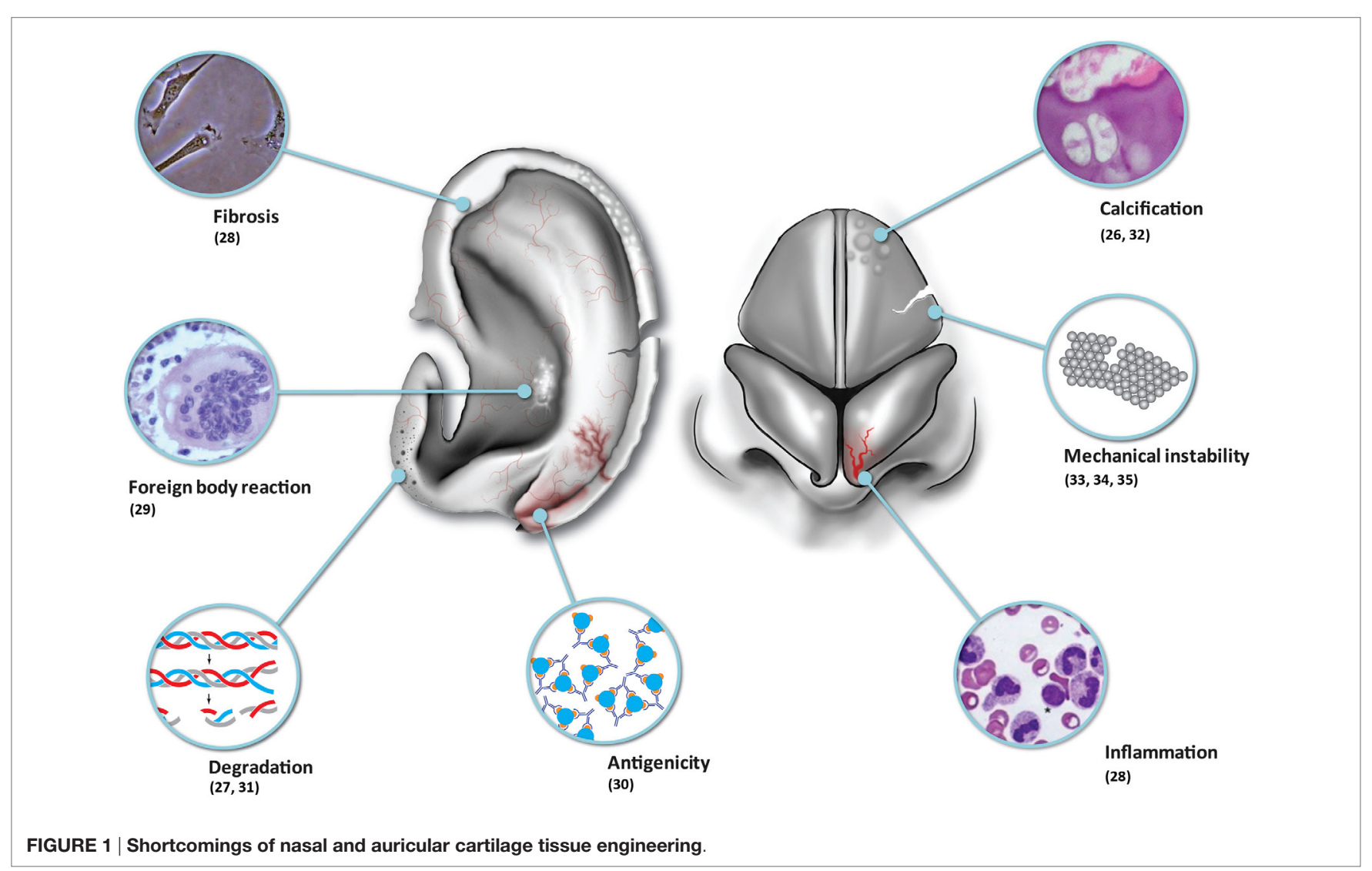




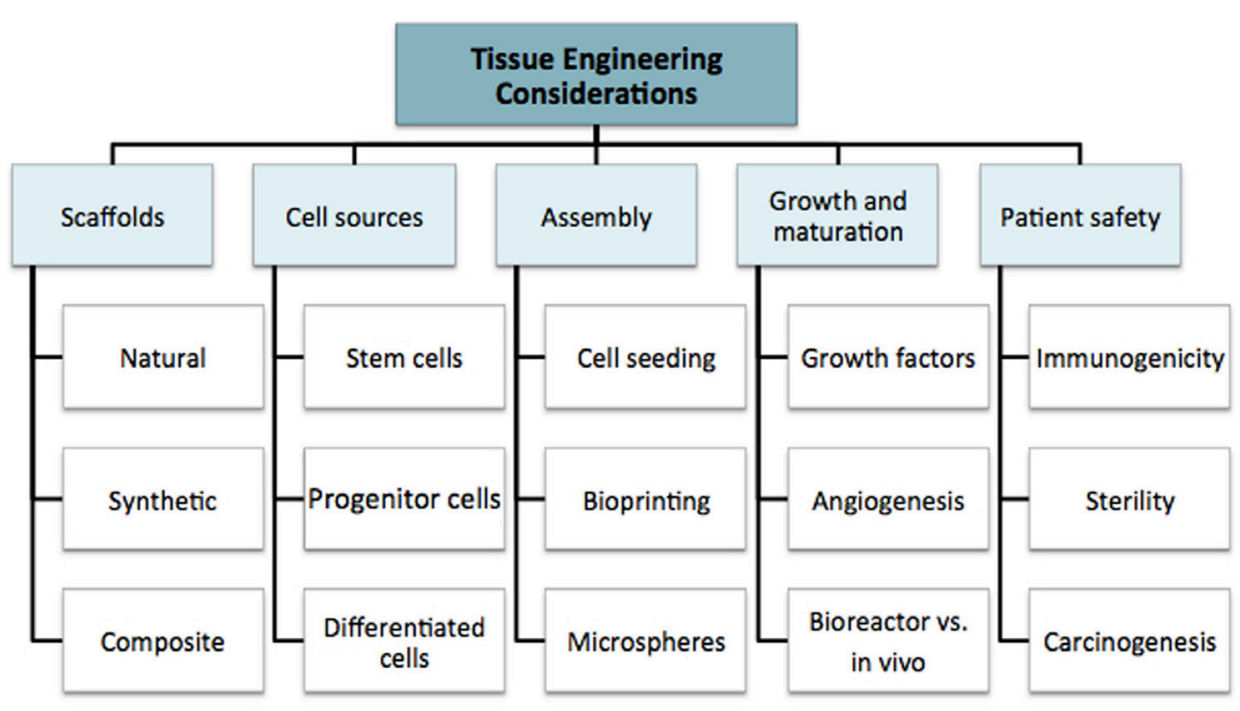

FIGURE 2 | Considerations in the field of tissue engineering

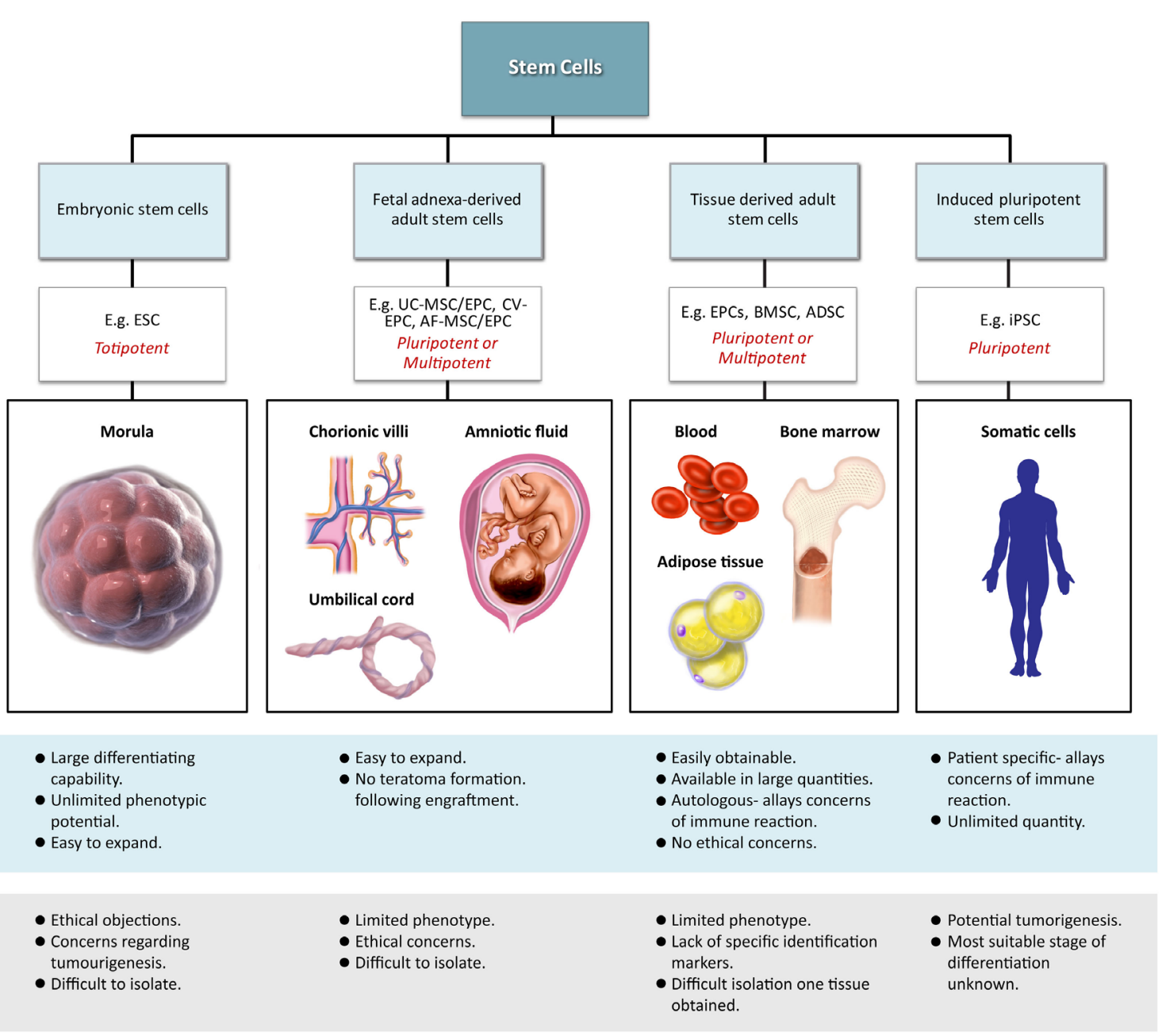

FIGURE 3 | Advantages and disadvantages of different cell sources utilized in tissue engineering 
maintenance of maturation are important for providing durability of the tissue-engineered construct.

\section{Cell Sources}

Classical tissue-engineering approaches use tissue-derived cells (not necessarily stem cells) seeded onto scaffolds (36). These cells may be autologous, allogenic, or xenogenic cells; however, autologous cells are the preferred choice due to the lack of immunogenicity. Cells may be further classified based on differences in their differentiating capabilities (Figure 3). Adult somatic cells are fully differentiated, and therefore have restricted future differentiation potential and relatively poor growth, limiting their usefulness for tissue-engineering purposes (37). Progenitor cells are more differentiated than stem cells and are therefore referred to as multipotent rather than pluripotent (38). Stem cells are non-differentiated cells, able to proliferate through multiple generations and differentiate into a variety of cell types $(39,40)$, and may overcome the limitations of differentiated cells (36) when used for tissue engineering. Pluripotent by definition, stem cells can be derived from embryonic, fetal, or adult (or postnatal somatic) tissue (39). Stem cells are the current preferred cell source for tissue-engineering endeavors and regenerative medicine therapies due to their high potency and capacity for expansion (41). Contemporary research efforts have focused on adult stem cells or progenitor cells for tissueengineering purposes. The use of embryonic and fetal tissue, although providing pluripotent stem cells with high proliferative potential, raises potential ethical issues as well as safety concerns over tumorigenic potential $(42,43)$. Adult derived stem cells, which are found among differentiated cells, have been isolated from an increasingly varied number of tissues over the past decade such as bone marrow (i.e., mesenchymal stem cells and hematopoietic stem cells), adipose [adipose-derived stem cells (44)], epithelial (epithelial-derived stem cells), and umbilical cord (cord blood stem cells) tissue (43). Developments made in isolation and culture of adult derived stem cells have improved cell yield during harvest. Subsequent research has focused on manipulating proliferation and differentiation into the desired cell type (45). Adult derived stem cells can only divide a finite number of times and accumulate genetic changes that can limit their supply for tissue-engineering purposes. The discovery of induced pluripotent stem cells (iPSCs) by Takahashi and Yamanaka (46) introduced the idea that a mature differentiated cell could be reverted to a state of pluripotency and multilineage potential (Figure 4). While this process, which has been shown to be possible with human cells, creates a potentially limitless source of easily accessible stem cells, it is not without drawbacks (47). Reprograming the cells has raised questions about

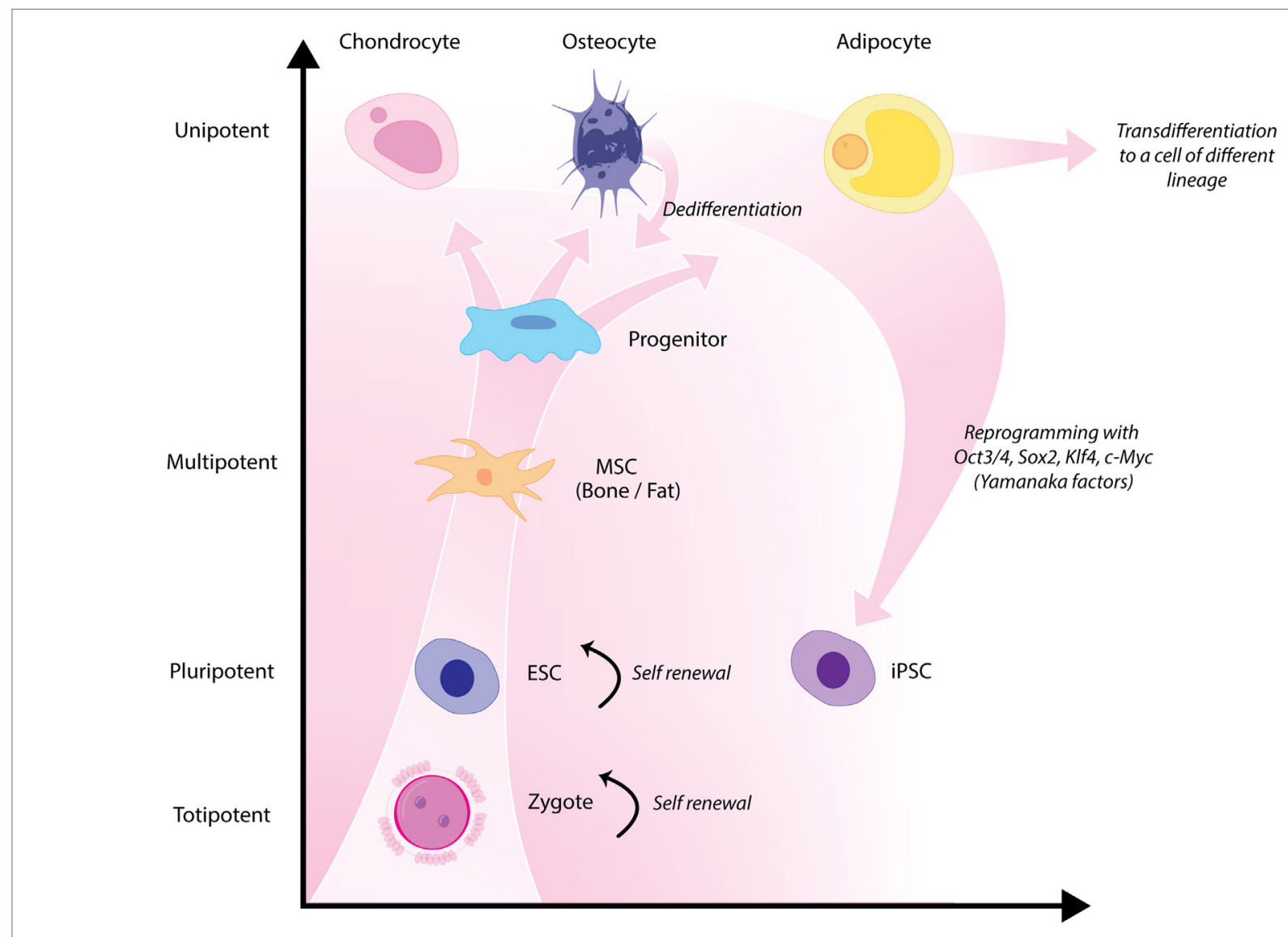

FIGURE 4 | Hierarchy of stem cells highlighting different degrees of potency. Yamanaka factors are used to induce differentiated cells to become pluripotent. 
epigenetic effects in particular, with a number of papers purporting to show DNA errors that have arisen during the process of inducing pluripotency $(47,48)$. Questions have also been raised regarding immunogenicity of engineered tissues with iPSCs implanted into a genetically identical mouse able to provoke an unexpected T cell-mediated immune response (49).

To better understand the behavior of specific cell types and their utility for tissue-engineering purposes, there is an increased reliance on advanced technologies (41) to monitor cell phenotype, migration, proliferation, migration, and differentiation both in vitro and in vivo. Impedance-based systems such as iCELLigence system (ACEA Biosciences) as well as Seahorse $\mathrm{XF}^{\mathrm{e}} 24$ Extracellular Flux Analyzer are allowing real-time monitoring of cellular processes and offer distinct and important advantages over traditional endpoint assays (Figure 5). Contemporary imaging modalities such as two photon excited fluorescence microscopy (50) and Raman spectroscopy (51), both with high resolution and depth of penetration $(>100 \mathrm{~nm}$, $300 \mathrm{~nm}$ and $1 \mathrm{~mm}, 0.4 \mathrm{~mm}$, respectively) are giving researchers clearer insights into the behavior of different cell types (Figure 5).

Further complications arise from the wide donor-to-donor variation in the behavior of cells, particularly stem cell populations, that has become apparent. Human adipose-derived stem cells, an increasingly prevalent source of adult stem cells for studies in tissue engineering, exhibit high donor-to-donor variability with regard to proliferation and differentiation characteristics, and this is not explained simply by donor age (52).

Currently, there is no consensus on the ideal cell source for tissue-engineering purposes. A thorough understanding of the advantages and disadvantages of each cell type is crucial to decide on cell selection and the optimal culture conditions in order to engineer specific tissue types.

\section{Scaffold Choices}

An appropriate scaffold is crucial to any tissue-engineering strategy. The ideal scaffold provides a framework for cell growth and development, allowing cells to attach, migrate, proliferate, and differentiate while facilitating cellular reorganization into a functional 3D network (Table 2).

Desirable characteristics of scaffolds include the following:

- Biomimetic (53)

- Biodegradable (with site specific absorption kinetics) (54-56)

- Appropriate mechanical strength

- Optimal micropores: enabling vascularization and allowing metabolic needs to be met (oxygen and waste product transfer)

- Biocompatible (57)

- Non-immunogenic (58)

- Versatile with regard to manufacturing methods

- Functionalization potential (59)
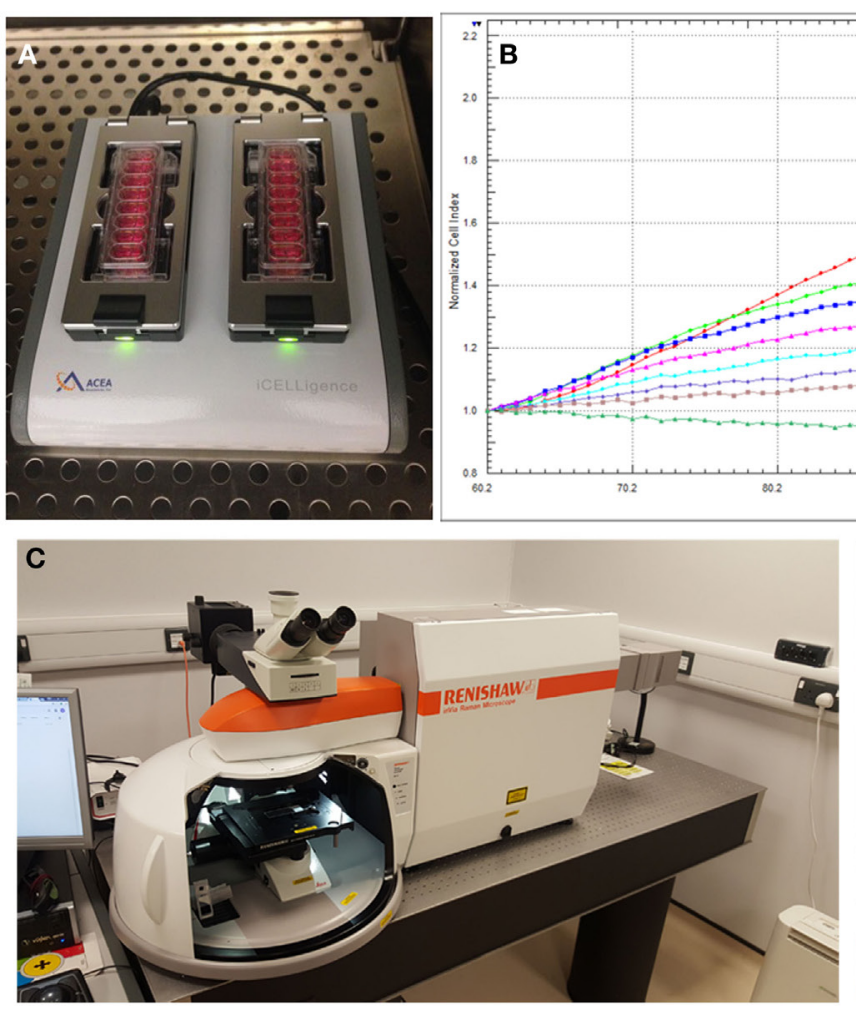

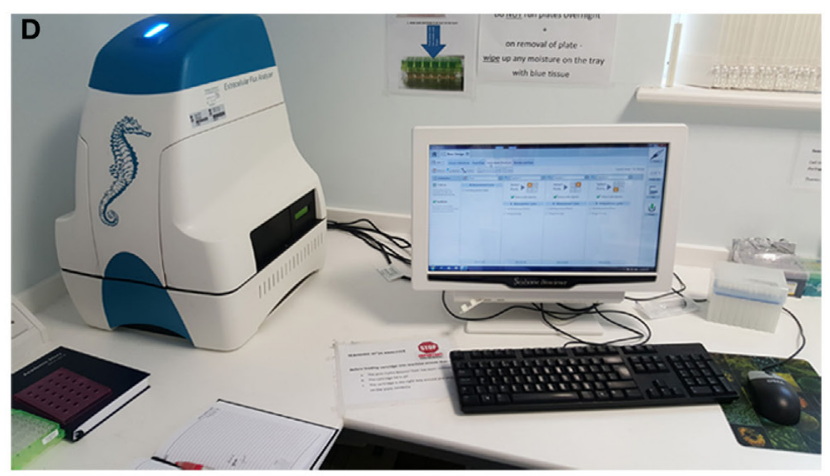

FIGURE 5 | Advanced technologies for monitoring cell behavior and survival. (A) ICELLigence impedance based cell assay machine. (B) Proliferation curves at different cell seeding densities generated by iCELLigence. (C) The Renishaw inVia confocal Raman microscope allows identification of stem cells based on the scattering of photons due to vibrations of molecular bonds. (D) Seahorse XFe24 Extracellular Flux Analyzer is used for measurement of cellular bioenergetics. 
TABLE 2 | Advantages and disadvantages of biomaterials utilized currently as scaffolds in tissue engineering.

\begin{tabular}{|c|c|c|c|c|c|c|}
\hline $\begin{array}{l}\text { Scoffold } \\
\text { class }\end{array}$ & Scoffold subtype & Macrostructure & Microstructure & $\begin{array}{l}\text { Chemical } \\
\text { composition }\end{array}$ & Advantages & Disadvantages \\
\hline \multirow[t]{3}{*}{ Synthetic } & Polylactic acid (PLA) & & & & $\begin{array}{l}\text { - More predictable and } \\
\text { reproducible mechanical and } \\
\text { physical properties } \\
\text { - High tensile strength, } \\
\text { degradation rate, and elastic } \\
\text { modulus (7) } \\
\text { - More readily available } \\
\text { - Relatively inexpensive }\end{array}$ & $\begin{array}{l}\text { - Immune reaction } \\
\text { - Lack biological cues (8) } \\
\text { - Toxicity } \\
\text { - Infections }\end{array}$ \\
\hline & Polyglycolic acid (PGA) & & & & & \\
\hline & $\begin{array}{l}\text { Polyethylene glycol } \\
\text { derivatives (PEG) }\end{array}$ & & & & & \\
\hline \multirow[t]{3}{*}{ Biological } & Fibrin & & & & $\begin{array}{l}\text { - } \text { Biocompatibility } \\
\text { - } \text { Cell-controlled degradability } \\
\text { - Intrinsic cellular interaction } \\
\text { - Hydrated environment } \\
\text { - Non-toxic } \\
\text { - Mucoadhesive }\end{array}$ & $\begin{array}{l}\text { - } \text { Batch variations } \\
\text { - Limited range of mechanical } \\
\text { properties } \\
\text { - Less reproducible } \\
\text { - Costly } \\
\text { - Specific processing conditions (10) }\end{array}$ \\
\hline & Elastin & & & & & \\
\hline & Collagen & & & & & \\
\hline
\end{tabular}




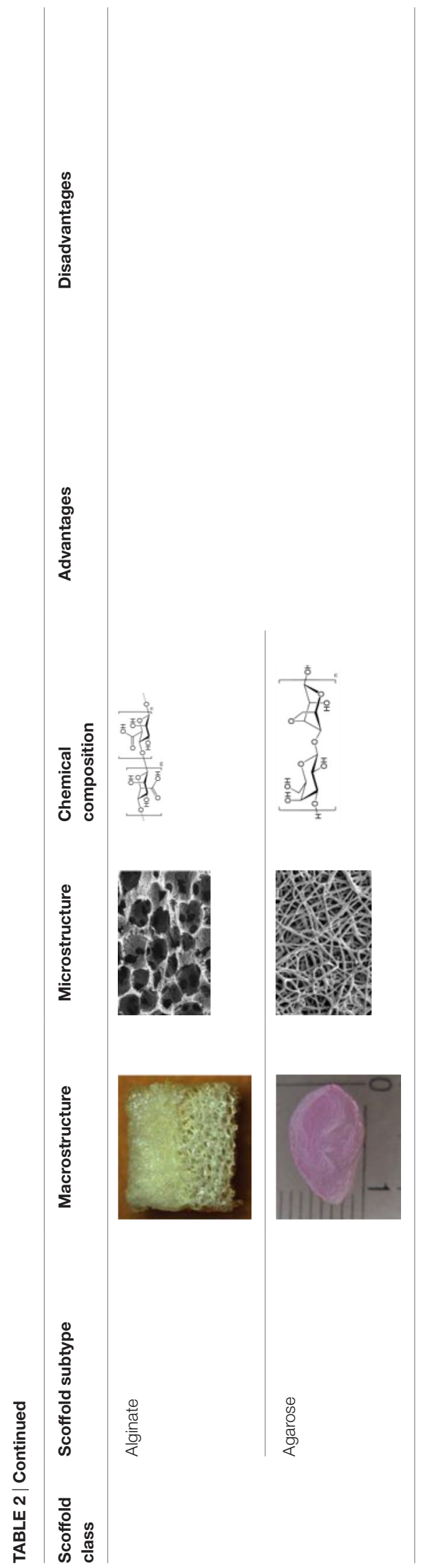

- 3D control of macroarchitecture

- Various nano- and micro-topographies, stiffnesses, and microenvironments appropriate to the proliferation, migration, and maturation of native or engrafted cells

- Suitable for clinical grade sterilization

- Suitable for industrial production.

Scaffolds are generally classified as biological (organic) or synthetic (inorganic). Engineering of the cell-scaffold construct can be undertaken in vitro in a bioreactor or in vivo by implanting the construct into the body. Advances in engineering, material science, and biomanufacturing technologies have enabled the design and development of more complex scaffolds using self assembly (60), computer modeling, bioprinting, and nanotechnology (60-62). "Functionalized," "decorated," or "smart" biomaterials that incorporate of biomolecular moieties on the surface, aim to orchestrate, and optimize the attachment and growth of cells and the synthesis of new tissue $(61,63)$. Scaffold size is largely limited by the lack of effective vascularization. Most successful work in the field focuses on understanding native tissue constituents and microarchitecture to allow accurate reproduction of functional tissue (64).

\section{Environment}

Consideration of the biophysiochemical $3 \mathrm{D}$ environment is crucial for tissue engineering. Cells not only require a scaffold for structural and biological support but also require an environment that provides the correct combination of growth supplements, differentiation signals, perfusion of nutrients, gaseous/waste exchange, $\mathrm{pH}$ regulation, and mechanical forces. The metabolic requirements of different tissues are varied and dictate the perfusion, gaseous/waste exchange, $\mathrm{pH}$, and mechanical environment required. There is an increasing awareness that molecular and mechanical signaling is pivotal in the growth and differentiation of tissue-engineered constructs, and in addition to well-known growth factors such as bone morphogenetic proteins, vascular epithelial growth factor, basic fibroblast growth factor FGF-2, and transforming growth factor- $\beta$ (65), "induction factors," including oxygen tension (66-68), mechanical (69), and electrical stimulation (70), guide subsequent proliferation and differentiation of cells. Cells participate in a web of multidirectional interactions within their niches and tissues of residence [interacting with various nanotopographically sized cues (71)]. This has implications during biomimetic tissue engineering, where the cellular environment (biomolecules), scaffold topography, and other external factors (mechanical and electrical stimulation) require regulation. This is complicated by the fact that cells not only respond to multiple stimuli but also have a direct impact on the environment themselves.

Research in this field is at the interface of cell biologists, engineers, materials scientists, and clinicians and is expanding rapidly. Multidisciplinary teams are working on bioreactor technology, which is vital for in vitro tissue engineering. Optimal conditions can to a great extent be applied and controlled through the use of bioreactors to mimic required conditions (72), and specialized bioreactors to help engineer a range of tissues have been developed in recent years $(73,74)$. Bioreactors are 




FIGURE 6 | Different environmental stimuli and the fundamental components of bioreactor technology

increasingly being used to provide more complex environments, exposing cells to a range of controllable electrical, electromagnetic, biomolecular, and mechanical cues while varying cell-cell or cell-matrix interactions (Figure 6) (73).

\section{CURRENT BARRIERS TO TRANSLATION}

Tissue engineering has the potential for major clinical impact in plastic and reconstructive surgery. Some products using tissueengineering concepts are already on the market; however, the panacea of functional vascularized composite tissue-engineered constructs is still theoretical. Translation of good basic science research from the laboratory to clinical reality remains a considerable challenge (Figure 7). In addition to meeting the scientific challenges of engineering durable and functional tissue for implantation into patients (75), one must also navigate the complex regulatory processes. The regulations controlling the delivery of stem cell therapeutics to the clinic parallel many of those developed for the pharmaceutical industry $(76,77)$. Guidelines governing the development of cell-based products can be found on websites for the U.S. Food and Drug Administration (FDA), ${ }^{1}$ the European Medicines Agency, ${ }^{2}$ and related governmental regulatory authorities. The United States Pharmacopeia is an internationally recognized resource defining the currently accepted industry standards for product purity, potency, and quality assurance. ${ }^{3}$ These targets are hard to meet outside a large,

${ }^{1}$ http://www.fda.gov/.

${ }^{2} \mathrm{http} / / / \mathrm{www} . e m a . e u r o p a . e u / e m a$.

${ }^{3}$ http://www.usp.org/. 
well-equipped commercial enterprise. Many research laboratories attached to clinical facilities do not produce mesenchymal stem cells in accordance with the criteria for either GLP or the more stringent cGMP, both requiring strict operational and certification records relating to all laboratory equipment and reagents used in the cell manufacture process $(1,4,5)$.

A clear understanding of the manufacturing workflow is required to allow autologous and allogeneic tissue-engineered product integration into clinical practice (78). Once cells are obtained from a donor, they must be stored in specialized banks and both "scaled-up" (increasing batch size) and "scaled out" (increasing number of batches). There are several challenges in mass production alone including the monitoring of product yield and ensuring purity, potency, and viability throughout the process. Mass production of autologous tissue requires a facility allowing multiple, parallel, patient-specific production lines. Where scaffolds are required, testing and maintenance of quality attributes needs to be undertaken prior to seeding (78). Additional challenges include storage/transportation, contamination, and obtaining regulatory approval.

The long-term safety, efficacy, and functionality of the products also need to be closely assessed (79). Practical considerations

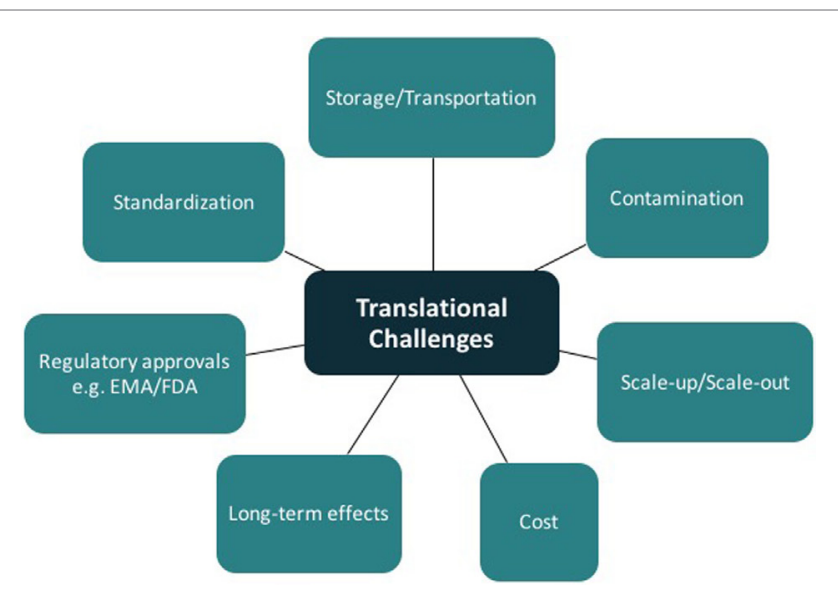

FIGURE 7 | Barriers to translation in tissue engineering that need to be contemplated include the storage environment and shelf life of the manufactured products.

It is also of interest that tissue-engineered products do not easily conform to either of the traditional Food and Drug Administration classification: biologics or devices $(80,81)$. Combined scaffold and cell-containing devices may be in more than one classification category. For devices, a single confirmatory study is often sufficient for FDA approval. If the product is regulated as a biologic, it must be reviewed and approved by the FDA Center for Biologics Evaluation and Research. If regulated as a drug, several further phases are required prior to FDA approval. Although these regulatory processes above present significant challenges, many countries do have streamlined regulatory processes that might reduce the obstacles faced (82).

\section{TISSUE ENGINEERING - WHERE ARE WE NOW?}

Stable and physiologically relevant (74) tissue replacement with composite engineered tissue remains elusive. Allograft transplantation has been an exciting development for the reconstructive surgeon, but the requirement for long-term immunosuppressive therapy (83), health-care infrastructure, and funding streams means it is not mainstream practice (Table 3). Tissue engineering is a promising alternative and has yielded small successes so far. Atala et al. were the first to report tissue-engineered constructs being used in patients (84). This was followed by several reports between 2008 and 2014 in a range of tissues including the trachea $(85,86)$, urethra (87), and nasal cartilage (88). Results have been varied; tracheal work is currently under investigation due to the deaths of three out of six patients and for nasal cartilage in particular, there was a question mark whether the tissue was replaced by scar or native tissue (89). The current significant barriers to translation for large-volume tissue replacement are the inability to produce "physiologicallty relevant tissue" (74) and difficulties with vascularization (24). Small constructs may succeed based on local angiogenesis $(84,87)$; however, the metabolic needs of the implanted cells in larger constructs means prevascularisation or the use of vascular pedicles is likely to be necessary (87).

TABLE 3 | Successful applications of tissue-engineered constructs in humans.

\begin{tabular}{|c|c|c|c|c|}
\hline $\begin{array}{l}\text { Organ/ } \\
\text { tissue }\end{array}$ & $\begin{array}{c}\text { No. of } \\
\text { patients }\end{array}$ & Cell source & Outcomes & Reference \\
\hline Bladder & 7 & $\begin{array}{l}\text { Bladder urothelial and muscle } \\
\text { cells }\end{array}$ & $\begin{array}{l}\text { Improved volume and compliance with no metabolic consequences at mean } 46 \text { months } \\
\text { follow-up }\end{array}$ & Atala et al. (84) \\
\hline Trachea & 1 & Recipient MSCs & Functional airway with a normal appearance and mechanical properties at 4 months & Macchiarini et al. (85) \\
\hline Urethra & 5 & Muscle and epithelial cells & $\begin{array}{l}\text { Maintenance of wide urethral calibers without strictures, normal architecture on biopsy at } \\
3 \text { months following implantation }\end{array}$ & $\begin{array}{l}\text { Raya-Rivera } \\
\text { et al. (87) }\end{array}$ \\
\hline $\begin{array}{l}\text { Nasal } \\
\text { cartilage }\end{array}$ & 5 & $\begin{array}{l}\text { Autologous nasal } \\
\text { chondrocytes }\end{array}$ & Good structural stability and respiratory function after 1 year & Fulco et al. (88) \\
\hline $\begin{array}{l}\text { Vaginal } \\
\text { organs }\end{array}$ & 4 & $\begin{array}{l}\text { Vulval biopsy-epithelial and } \\
\text { muscle cells }\end{array}$ & $\begin{array}{l}\text { Tri-layered structure on biopsy with phenotypically normal smooth muscle and epithelia } \\
\text { with follow-up up to } 8 \text { years }\end{array}$ & $\begin{array}{l}\text { Raya-Rivera } \\
\text { et al. (90) }\end{array}$ \\
\hline
\end{tabular}




\section{CONCLUSION AND FUTURE PERSPECTIVES}

Surgical reconstruction using bioengineered tissues has the potential to revolutionize clinical practice. To be successful, one must be able to generate tissue constructs in vitro that are morphologically and functionally similar to native tissues. There has been a steady increase in basic science activity in cell therapy and a growing portfolio of cell therapy trials; however, this has not translated to commercial products available for clinical use. To achieve clinical translation, a multidisciplinary approach that successfully integrates engineering and biological methodologies is necessary. Ethical, regulatory, financial, and clinical considerations all present challenges in the translation of tissue-engineered constructs from the laboratory to mainstream clinical practice. Even though The Medical Research Council states that regenerative medicine and tissue engineering "holds the promise of revolutionizing patient care in the 21 st century" (91) and that stem cell therapy is viewed as a future "game changer" by the plastic surgery community (92), many are yet to be convinced of this potential within the NHS, with major concerns involving cost-effectiveness, efficacy, reimbursement, and regulation (93). There is little doubt that tissue engineering offers great potential to reduce patient morbidity and mortality, and only co-ordinated and prolonged liaison between clinicians, scientists, and industry will move this from potential to reality.

\section{GLOSSARY}

\section{Cell Biology}

Differentiation-The process by which a cell becomes specialized in order to perform a specific function.

Commitment-When a cell becomes dedicated to a specific lineage.

Potency-The array of commitment opportunities available to a cell.

Totipotent-Cells capable of differentiating into any body cell type in addition to extraembryonic or placental cells.

Multipotent-Cells capable of differentiating into multiple cell types along one lineage (e.g., hematopoietic stem cells).

Pluripotent-Cells that may differentiate into tissues derived from all three germ cell layers.

Unipotent-Cells only capable of differentiating into one cell type (e.g., spermatogonial stem cells).

Clonal-A population of identical cells derived from the same cell.

Polyclonal-A population of cells derived from multiple clones.

Progenitor-A cell that has limited potency, but is able to differentiate to another cell type, or differentiate to its target cell lineage.

Embryonic stem cells-Embryonically derived pluripotent cells that are obtained from the inner cell mass.

Induced pluripotent stem cells-Differentiated cells that are reverted to their pluripotent state via a set of transcription factors.

Autologous-Cells or tissues obtained from the same individual.
Allogeneic-Cells or tissues obtained from a different individual of the same species.

Xenogeneic-Cells or tissues obtained from a different species.

Extracellular matrix-Biomolecules synthesized by the cell to provide a suitable environment to support surrounding cells and maintain tissue integrity in response to biochemical and mechanical cues.

\section{Biomaterials/Scaffolds}

Scaffold-A 3D biomaterial construct that defines the geometry of the replacement tissue and provides environmental cues that promote tissue regeneration.

Biomimetic-Human-made substances, e.g., scaffolds that imitate nature.

Functionalization - The modification of scaffolds with bioactive material to enhance the biocompatibility of the scaffold.

Nanotechnology-Technology that deals with dimensions and tolerances of less than $100 \mathrm{~nm}$, especially the manipulation of individual atoms and molecules.

Biomolecular factors-Biomolecular factors include growth factors, transcription factors, and components of the extracellular matrix.

Mechanical factors-External environmental stimuli such as forces generated during everyday movement.

\section{Manufacturing}

Bioprinting - the process of generating spatially controlled cell patterns using 3D printing technologies.

Bioreactor-System in which conditions are closely controlled to permit or induce certain behavior in living cells or tissues.

Good Laboratory Practice (GLP) - System of management controls for laboratories conducting research to ensure consistency, reliability, reproducibility, and high quality of chemical (including pharmaceutical) tests.

Good Manufacturing Practice (GMP) guidelinesRegulatory guidelines that outline specific requirements for the handling and processing of human tissue, ensuring safe products of reliable quality.

Scale-out-Increasing the number of batches of an engineered product.

Scale-up-Increasing batch size on an engineered product.

\section{AUTHOR CONTRIBUTIONS}

SA-H and ZJ completed a literature search and contributed to preparing the manuscript. AA-S, EC, and AI contributed ideas and content to the manuscript. SD, AH, CT, and CA critically revised the manuscript. IW conceived, contributed to the preparation of, and critically revised the manuscript. All the authors read and approved the final manuscript and agreed to be accountable for all aspects of the work.

\section{ACKNOWLEDGMENTS}

The Reconstructive Surgery and Regenerative Medicine Research Group (ReconRegen) is currently supported by funding from 
the Royal College of Surgeons of England, British Association of Plastic, Reconstructive and Aesthetic Surgeons (BAPRAS), Medical Research Council (MR/N002431/1), ABMU Health

\section{REFERENCES}

1. Pratt GF, Rozen WM, Chubb D, Ashton MW, Alonso-Burgos A, Whitaker IS. Preoperative imaging for perforator flaps in reconstructive surgery: a systematic review of the evidence for current techniques. Ann Plast Surg (2012) 69(1):3-9. doi:10.1097/SPA.0b013e318222b7b7

2. Taylor GI, Daniel RK. The free flap: composite tissue transfer by vascular anastomosis. Aust NZJ Surg (1973) 43(1):1-3. doi:10.1111/j.1445-2197.1973. tb05659.x

3. Shores JT, Brandacher G, Lee WPA. Hand and upper extremity transplantation: an update of outcomes in the worldwide experience. Plast Reconstr Surg (2015) 135(2):351e-60e. doi:10.1097/PRS.0000000000000892

4. Khalifian S, Brazio PS, Mohan R, Shaffer C, Brandacher G, Barth RN, et al. Facial transplantation: the first 9 years. Lancet (2014) 384(9960):2153-63. doi:10.1016/S0140-6736(13)62632-X

5. Nodzo SR, Hohman DW, Chakravarthy K. Nanotechnology: why should we care? Am J Orthop (2015) 44(3):E87-8.

6. Naderi H, Matin MM, Bahrami AR. Review paper: critical issues in tissue engineering: biomaterials, cell sources, angiogenesis, and drug delivery systems. J Biomater Appl (2011) 26(4):383-417. doi:10.1177/0885328211408946

7. Murphy SV, Atala A. 3D bioprinting of tissues and organs. Nat Biotechnol (2014) 32(8):773-85. doi:10.1038/nbt.2958

8. Gerstle TL, Ibrahim AM, Kim PS, Lee BT, Lin SJ. A plastic surgery application in evolution: three-dimensional printing. Plast Reconstr Surg (2014) 133(2):446-51. doi:10.1097/01.prs.0000436844.92623.d3

9. Chae MP, Rozen WM, McMenamin PG, Findlay MW, Spychal RT, HunterSmith DJ. Emerging applications of bedside 3D printing in plastic surgery. Front Surg (2015) 2:25. doi:10.3389/fsurg.2015.00025

10. Kamali P, Dean D, Skoracki R, Koolen PG, Paul MA, Ibrahim AM, et al. The current role of three-dimensional (3D) printing in plastic surgery. Plast Reconstr Surg (2016). doi:10.1097/PRS.0000000000003106

11. Golas AR, Hernandez KA, Spector JA. Tissue engineering for plastic surgeons: a primer. Aesthetic Plast Surg (2014) 38(1):207-21. doi:10.1007/ s00266-013-0255-5

12. Whitaker I, Boyce E. Dismissing the myths: an analysis of 12,483 procedures. All in a years work for a plastic surgical unit. Internet $J$ World Health Soc Politics (2009) 6(2).

13. Hospital Episode Statistics, Admitted Patient Care, England 2012-13. Health and Social Care Information Centre (2015). Available from: http://www. hscic.gov.uk/catalogue/PUB12566

14. Hospital Episode Statistics, Outpatient Care. Health and Social Care Information Centre (2015). Available from: http://www.hscic.gov.uk/ searchcatalogue? productid=18356\&q=title $\% 3 \mathrm{a} \% 22 \mathrm{hospital}+$ episode+statistics $\% 22 \&$ sort $=$ Relevance\&size $=10 \&$ page $=1 \#$ top

15. Recommendation for Plastic Surgery Training 2011. UK: Centre for Workforce Intelligence a Report from the Royal College of Surgeons of England (2015). Available from: http://www.rcseng.ac.uk/surgeons/surgical-standards/ docs/2011-surgical-workforce-census-report

16. Søreide K. Epidemiology of major trauma. Br J Surg (2009) 96(7):697-8. doi:10.1002/bjs.6643

17. Sterodimas A, De Faria J, Correa WE, Pitanguy I. Tissue engineering in plastic surgery: an up-to-date review of the current literature. Ann Plast Surg (2009) 62(1):97-103. doi:10.1097/SAP.0b013e3181788ec9

18. Skalak R, Fox CF. Tissue Engineering: Proceeding of a Workshop Held at Granlibakken, Lake Tahoe, California. New York: Liss (1998).

19. Ikada Y. Challenges in tissue engineering. J $R$ Soc Interface (2006) 3(10):589-601. doi:10.1098/rsif.2006.0124

20. Pallua N, Gröger A. Tissue engineering and plastic surgery. In: Klein ME, Neuhann-Lorenz C, editors. Innovations in Plastic and Aesthetic Surgery. Berlin, Heidelberg: Springer (2008). p. 17-23.

21. D'Amico RA, Rubin JP. Regenerative medicine and the future of plastic surgery. Plast Reconstr Surg (2014) 133(6):1511-2. doi:10.1097/ PRS.0000000000000212
Board, and Welsh Assembly Government. The authors thank Mr. Steve Atherton and Ms. Amy Shorter, medical illustrators, ABMU Health Board, for figures.

22. Committee GBP HOLSAT. House of Lords - Select Committee on Science and Technology - HL 76. London: The Stationery Office Limited (2013).

23. O'Dowd A. Peers call for UK to harness "enormous" potential of regenerative medicine. Br Med J (2013) 347:f4248. doi:10.1136/bmj.f4248

24. Findlay MW, Dolderer JH, Trost N, Craft RO, Cao Y, Cooper-White J, et al. Tissue-engineered breast reconstruction: bridging the gap toward large-volume tissue engineering in humans. Plast Reconstr Surg (2011) 128(6):1206-15. doi:10.1097/PRS.0b013e318230c5b2

25. Freese KE, Kokai L, Edwards RP, Philips BJ, Sheikh MA, Kelley J, et al. Adipose-derived stems cells and their role in human cancer development, growth, progression, and metastasis: a systematic review. Cancer Res (2015) 75(7):1161-8. doi:10.1158/0008-5472.CAN-14-2744

26. Bichara DA, O'Sullivan NA, Pomerantseva I, Zhao X, Sundback CA, Vacanti JP, et al. The tissue-engineered auricle: past, present, and future. Tissue Eng Part B Rev (2012) 18:51-61. doi:10.1089/ten.TEB.2011.0326

27. Cao Y, Vacanti JP, Paige KT, Upton J, Vacanti CA. Transplantation of chondrocytes utilizing a polymer-cell construct to produce tissue-engineered cartilage in the shape of a human ear. Plast Reconstr Surg (1997) 100:297-302. doi:10.1097/00006534-199708000-00001

28. Kamil SH, Vacanti MP, Aminuddin BS, Jackson MJ, Vacanti CA, Eavey RD. Tissue engineering of a human sized and shaped auricle using a mold. Laryngoscope (2004) 114:867. doi:10.1097/00005537-200405000-00015

29. Christophel JJ, Chang JS, Park SS. Transplanted tissue-engineered cartilage. Arch Facial Plast Surg (2006) 8(2):117-22. doi:10.1001/archfaci.8.2.117

30. Nayyer L, Patel KH, Esmaeili A, Rippel RA, Birchall M, O'Toole G, et al. Tissue engineering: revolution and challenge in auricular cartilage reconstruction. Plast Reconstr Surg (2012) 129(5):1123-37. doi:10.1097/ PRS.0b013e31824a2c1c

31. Brommer H, Brama PAJ, Laasanen MS, Helminen HJ, van Weeren PR, Jurvelin JS. Functional adaptation of articular cartilage from birth to maturity under the influence of loading: a biomechanical analysis. Equine Vet J (2005) 37(2):148-54. doi:10.2746/0425164054223769

32. Kusuhara H, Isogai N, Enjo M, Otani H, Ikada Y, Jacquet R, et al. Tissue engineering a model for the human ear: assessment of size, shape, morphology, and gene expression following seeding of different chondrocytes. Wound Repair Regen (2009) 17(1):136-46. doi:10.1111/j.1524-475X.2008.00451.x

33. Nabzdyk C, Pradhan L, Molina J, Perin E, Paniagua D, Rosenstrauch D. Auricular chondrocytes-from benchwork to clinical applications. In Vivo (2009) 23(3):369-80

34. Homicz MR, Schumacher BL, Sah RH, Watson D. Effects of serial expansion of septal chondrocytes on tissue-engineered neocartilage composition. Otolaryngol Head Neck Surg (2002) 127:398-408. doi:10.1067/ mhn.2002.129730

35. Jian-Wei X, Randolph MA, Peretti GM, Nazzal JA, Roses RE, Morse KR, et al. Producing a flexible tissue-engineered cartilage framework using expanded polytetrafluoroethylene membrane as a pseudoperichondrium. Plastic Reconstr Surg (2005) 116(2):577-89. doi:10.1097/01.prs.0000172985.81897.dc

36. Bianco P, Robey PG. Stem cells in tissue engineering. Nature (2001) 414(6859):118-21. doi:10.1038/35102181

37. Guillot PV, Cui W, Fisk NM, Polak DJ. Stem cell differentiation and expansion for clinical applications of tissue engineering. J Cell Mol Med (2007) 11(5):935-44. doi:10.1111/j.1582-4934.2007.00106.x

38. Shi Q, Rafii S, Wu MH, Wijelath ES, Yu C, Ishida A, et al. Evidence for circulating bone marrow-derived endothelial cells. Blood (1998) 92(2):362-7.

39. Thomson JA, Itskovitz-Eldor J, Shapiro SS, Waknitz MA, Swiergiel JJ, Marshall VS, et al. Embryonic stem cell lines derived from human blastocysts. Science (1998) 282(5391):1145-7. doi:10.1126/science.282.5391.1145

40. Dominici M, Le Blanc K, Mueller I, Slaper-Cortenbach I, Marini F, Krause $\mathrm{D}$, et al. Minimal criteria for defining multipotent mesenchymal stromal cells. The International Society for Cellular Therapy position statement. Cytotherapy (2006) 8(4):315-7. doi:10.1080/14653240600855905

41. Kupfer ME, Ogle BM. Advanced imaging approaches for regenerative medicine: emerging technologies for monitoring stem cell fate in vitro 
and in vivo. Biotechnol $J$ (2015) 10(10):1515-28. doi:10.1002/biot. 201400760

42. Asano T, Sasaki K, Kitano Y, Terao K, Hanazono Y. In vivo tumor formation from primate embryonic stem cells. Methods Mol Biol (2006) 329: 459-67.

43. da Silva Meirelles L, Caplan AI, Nardi NB. In search of the in vivo identity of mesenchymal stem cells. Stem Cells (2008) 26(9):2287-99. doi:10.1634/ stemcells.2007-1122

44. Zuk PA, Zhu M, Mizuno H, Huang J, Futrell JW, Katz AJ, et al. Multilineage cells from human adipose tissue: implications for cell-based therapies. Tissue Eng (2001) 7(2):211-28. doi:10.1089/107632701300062859

45. Stock UA, Vacanti JP. Tissue engineering: current state and prospects. Annu Rev Med (2001) 52(1):443-51. doi:10.1146/annurev.med.52.1.443

46. Takahashi K, Yamanaka S. Induction of pluripotent stem cells from mouse embryonic and adult fibroblast cultures by defined factors. Cell (2006) 126(4):663-76. doi:10.1016/j.cell.2006.07.024

47. Hayden EC. Stem cells: the growing pains of pluripotency. Nature (2011) 9:272-4. doi:10.1038/473272a

48. Laurent LC, Ulitsky I, Slavin I, Tran H, Schork A, Morey R, et al. Dynamic changes in the copy number of pluripotency and cell proliferation genes in human ESCs and iPSCs during reprogramming and time in culture. Cell Stem Cell (2011) 8(1):106-18. doi:10.1016/j.stem.2010.12.003

49. Zhao T, Zhang Z-N, Rong Z, Xu Y. Immunogenicity of induced pluripotent stem cells. Nature (2011) 474(7350):212-5. doi:10.1038/nature10135

50. Chang T, Zimmerley MS, Quinn KP, Lamarre-Jouenne I, Kaplan DL, Beaurepaire E, et al. Non-invasive monitoring of cell metabolism and lipid production in 3D engineered human adipose tissues using label-free multiphoton microscopy. Biomater (2013) 34(34):8607-16. doi:10.1016/j. biomaterials.2013.07.066

51. Erlach von TC, Hedegaard MAB, Stevens MM. High resolution Raman spectroscopy mapping of stem cell micropatterns. Analyst (2015) 140(6):1798-803. doi:10.1039/c4an02346c

52. Bodle JC, Teeter SD, Hluck BH, Hardin JW, Bernacki SH, Loboa EG. Agerelated effects on the potency of human adipose-derived stem cells: creation and evaluation of superlots and implications for musculoskeletal tissue engineering applications. Tissue Eng Part C Methods (2014) 20(12):972-83. doi:10.1089/ten.TEC.2013.0683

53. Bhatnagar R, Li S. Biomimetic scaffolds for tissue engineering. Conf Proc IEEE Eng Med Biol Soc (2004) 7:5021-3. doi:10.1109/IEMBS.2004.1404387

54. Hollister SJ. Porous scaffold design for tissue engineering. Nat Mater (2005) 4(7):518-24. doi:10.1038/nmat1421

55. Hutmacher DW. Scaffolds in tissue engineering bone and cartilage. Biomaterials (2000) 21(24):2529-43. doi:10.1016/S0142-9612(00)00121-6

56. Rezwan K, Chen QZ, Blaker JJ, Boccaccini AR. Biodegradable and bioactive porous polymer/inorganic composite scaffolds for bone tissue engineering. Biomaterials (2006) 27(18):3413-31. doi:10.1016/j.biomaterials. 2006.01.039

57. Kim BS, Mooney DJ. Development of biocompatible synthetic extracellular matrices for tissue engineering. Trends Biotechnol (1998) 16(5):224-30. doi:10.1016/S0167-7799(98)01191-3

58. Lutolf MP, Hubbell JA. Synthetic biomaterials as instructive extracellular microenvironments for morphogenesis in tissue engineering. Nat Biotechnol (2005) 23(1):47-55. doi:10.1038/nbt1055

59. Sanghvi AB, Miller KP-H, Belcher AM, Schmidt CE. Biomaterials functionalization using a novel peptide that selectively binds to a conducting polymer. Nat Mater (2005) 4(6):496-502. doi:10.1038/nmat1397

60. Barnes CP, Sell SA, Boland ED, Simpson DG, Bowlin GL. Nanofiber technology: designing the next generation of tissue engineering scaffolds. Adv Drug Deliv Rev (2007) 59(14):1413-33. doi:10.1016/j.addr.2007.04.022

61. Furth ME, Atala A, Van Dyke ME. Smart biomaterials design for tissue engineering and regenerative medicine. Biomaterials (2007) 28(34):5068-73. doi:10.1016/j.biomaterials.2007.07.042

62. Wong YS, Tay CY, Wen F. Engineered polymeric biomaterials for tissue engineering. Curr Tissue Eng (2012) 1:41-53.

63. Anderson DG, Burdick JA, Langer R. Materials science. Smart biomaterials. Science (2004) 305(5692):1923-4. doi:10.1126/science.1099987

64. Lanza R, Langer R, Vacanti JP. Principles of Tissue Engineering. 4th ed. Academic Press (2013). 1 p.
65. Chen F-M, Zhang M, Wu Z-F. Toward delivery of multiple growth factors in tissue engineering. Biomaterials (2010) 31(24):6279-308. doi:10.1016/j. biomaterials.2010.04.053

66. Leijten J, Georgi N, Moreira Teixeira L, van Blitterswijk CA, Post JN, Karperien M. Metabolic programming of mesenchymal stromal cells by oxygen tension directs chondrogenic cell fate. Proc Natl Acad Sci U S A (2014) 111(38):13954-9. doi:10.1073/pnas.1410977111

67. Fotia C, Massa A, Boriani F, Baldini N, Granchi D. Prolonged exposure to hypoxic milieu improves the osteogenic potential of adipose derived stem cells. J Cell Biochem (2015) 116(7):1442-53. doi:10.1002/jcb. 25106

68. De Miguel MP, Alcaina Y, la Maza de DS, Lopez-Iglesias P. Cell metabolism under microenvironmental low oxygen tension levels in stemness, proliferation and pluripotency. Curr Mol Med (2015) 15(4):343-59. doi:10.2174/1 566524015666150505160406

69. Correia V, Panadero JA, Ribeiro C, Sencadas V, Rocha JG, Gomez Ribelles JL, et al. Design and validation of a biomechanical bioreactor for cartilage tissue culture. Biomech Model Mechanobiol (2016) 15(2):471-8. doi:10.1007/ s10237-015-0698-5

70. Hernández-Bule ML, Paíno CL, Trillo MÁ, Úbeda A. Electric stimulation at $448 \mathrm{kHz}$ promotes proliferation of human mesenchymal stem cells. Cell Physiol Biochem (2014) 34(5):1741-55. doi:10.1159/000366375

71. Griffin MF, Butler PE, Seifalian AM, Kalaskar DM. Control of stem cell fate by engineering their micro and nanoenvironment. World J Stem Cells (2015) 7(1):37-50. doi:10.4252/wjsc.v7.i1.37

72. Pörtner R, Nagel-Heyer S, Goepfert C, Adamietz P, Meenen NM. Bioreactor design for tissue engineering. J Biosci Bioeng (2005) 100(3):235-45. doi:10.1263/jbb.100.235

73. Hansmann J, Groeber F, Kahlig A, Kleinhans C, Walles H. Bioreactors in tissue engineering - principles, applications and commercial constraints. Biotechnol J (2013) 8(3):298-307. doi:10.1002/biot.201200162

74. Abbott RD, Kaplan DL. Strategies for improving the physiological relevance of human engineered tissues. Trends Biotechnol (2015) 33(7):401-7. doi:10.1016/j.tibtech.2015.04.003

75. Hunziker E, Spector M, Libera J, Gertzman A, Woo SL-Y, Ratcliffe A, et al. Translation from research to applications. Tissue Eng (2006) 12(12):3341-64. doi:10.1089/ten.2006.12.3341

76. Halme DG, Kessler DA. FDA regulation of stem-cell-based therapies. N Engl $J$ Med (2006) 355(16):1730-5. doi:10.1056/NEJMhpr063086

77. Fink DW. FDA regulation of stem cell-based products. Science (2009) 324(5935):1662-3. doi:10.1126/science.1173712

78. Hunsberger J, Harrysson O, Shirwaiker R, Starly B, Wysk R, Cohen P, et al. Manufacturing road map for tissue engineering and regenerative medicine technologies. Stem Cells Transl Med (2015) 4(2):130-5. doi:10.5966/ sctm.2014-0254

79. Berry MG, Stanek JJ. The PIP mammary prosthesis: a product recall study. J Plast Reconstr Aesthet Surg (2012) 65(6):697-704. doi:10.1016/j. bjps.2012.02.019

80. Lu L, Arbit HM, Herrick JL, Segovis SG, Maran A, Yaszemski MJ. Tissue engineered constructs: perspectives on clinical translation. Ann Biomed Eng (2015) 43(3):796-804. doi:10.1007/s10439-015-1280-0

81. Uppal RS, Sabbagh W, Chana J, Gault DT. Donor-site morbidity after autologous costal cartilage harvest in ear reconstruction and approaches to reducing donor-site contour deformity. Plast Reconstr Surg (2008) 121(6):1949-55. doi:10.1097/PRS.0b013e318170709e

82. Birchall MA, Seifalian AM. Tissue engineering's green shoots of disruptive innovation. Lancet (2014) 384(9940):288-90. doi:10.1016/ S0140-6736(14)60533-X

83. Whitaker IS, Duggan EM, Alloway RR, Brown C, McGuire S, Woodle ES, et al. Composite tissue allotransplantation: a review of relevant immunological issues for plastic surgeons. J Plast Reconstr Aesthet Surg (2008) 61(5):481-92. doi:10.1016/j.bjps.2007.11.019

84. Atala A, Bauer SB, Soker S, Yoo JJ, Retik AB. Tissue-engineered autologous bladders for patients needing cystoplasty. Lancet (2006) 367(9518):1241-6. doi:10.1016/S0140-6736(06)68438-9

85. Macchiarini P, Jungebluth P, Go T, Asnaghi MA, Rees LE, Cogan TA, et al. Clinical transplantation of a tissue-engineered airway. Lancet (2008) 372(9655):2023-30. doi:10.1016/S0140-6736(08)61598-6 
86. Baiguera S, Birchall MA, Macchiarini P. Tissue-engineered tracheal transplantation. Transplantation (2010) 89(5):485-91. doi:10.1097/ TP.0b013e3181cd4ad3

87. Raya-Rivera A, Esquiliano DR, Yoo JJ, Lopez-Bayghen E, Soker S, Atala A. Tissue-engineered autologous urethras for patients who need reconstruction: an observational study. Lancet (2011) 377(9772):1175-82. doi:10.1016/ S0140-6736(10)62354-9

88. Fulco I, Miot S, Haug MD, Barbero A, Wixmerten A, Feliciano S, et al. Engineered autologous cartilage tissue for nasal reconstruction after tumour resection: an observational first-in-human trial. Lancet (2014) 384(9940):337-46. doi:10.1016/S0140-6736(14)60544-4

89. Russell AJ. The end of the beginning for tissue engineering. Lancet (2014) 383(9913):193-5. doi:10.1016/S0140-6736(13)62110-8

90. Raya-Rivera AM, Esquiliano D, Fierro-Pastrana R, López-Bayghen E, Valencia P, Ordorica-Flores R, et al. Tissue-engineered autologous vaginal organs in patients: a pilot cohort study. Lancet (2014) 384(9940):329-36. doi:10.1016/S0140-6736(14)60542-0

91. Medical Research Council. Regenerative Medicine and Stem Cells. Available from: http://www.mrc.ac.uk/research/initiatives/regenerative-medicine-stemcells/ (accessed January 26, 2017).
92. Ozturk S, Karagoz H, Zor F. The future of plastic surgery: surgeon's perspective. J Craniofac Surg (2015) 26(8):e708-13. doi:10.1097/SCS.0000000000 002204

93. Davies BM, Rikabi S, French A, Pinedo-Villanueva R, Morrey ME, Wartolowska K, et al. Quantitative assessment of barriers to the clinical development and adoption of cellular therapies: a pilot study. J Tissue Eng (2014) 5(0):2041731414551764. doi:10.1177/2041731414551764

Conflict of Interest Statement: The authors declare that the research was conducted in the absence of any commercial or financial relationships that could be construed as a potential conflict of interest.

Copyright (c) 2017 Al-Himdani, Jessop, Al-Sabah, Combellack, Ibrahim, Doak, Hart, Archer, Thornton and Whitaker. This is an open-access article distributed under the terms of the Creative Commons Attribution License (CC BY). The use, distribution or reproduction in other forums is permitted, provided the original author(s) or licensor are credited and that the original publication in this journal is cited, in accordance with accepted academic practice. No use, distribution or reproduction is permitted which does not comply with these terms. 